\title{
QUALITY IMPROVEMENT ON CERAMIC TILES PROUCTION PROCESS WITH SIX SIGMA METHOD (DMAIC) AT PT ARWANA CITRAMULIA
}

\author{
Priskila Christine Rahayu', Vanesa Darvin² \\ ${ }^{1,2}$ Department of Industrial Engineering \\ Pelita Harapan University, Tangerang, Indonesia \\ Email : priskila.christine@uph.edu
}

\begin{abstract}
A b s trak
This study focused on quality improvement on ceramic tiles production process at PT Arwana Citramulia. This study used data defects for 12 months (May 2016 - April 2017) and only focus on one type of defect and it is chop corner. Six sigma with DMAIC (define, measure, analyze, improve, and control) approach was used to improve the process. Each step of DMAIC was conducted to carefully analyze and keep the process precisely. The ceramic tiles production process contains a number of 4375 products defects in million opportunities (DPMO), with sigma level of 4.13. In the improve step of DMAIC, FMEA form was used to propose some recommendations in order to improve the process, some of that that are provision of lubricant periodically by the operator, polishing on the surface of the liner to clean and clear, examination and maintenance periodically.
\end{abstract}

Keyword: Quality, Six Sigma, DMAIC, Defects.

\section{INTRODUCTION}

The development of the industrial world today demands competition among industries to get costumers. To win the competition, creating better quality products from competitors is the key, by creating and using strategies to compete in this tight market competition and can produce a good quality of products. If the product continues to qualify then the costumers will feel satisfied and then encourage costumers to buy again and again so that costumers will remain loyal.

A product can be said has its quality if the product is fit with the needs and desires of the customers, can be utilized properly, and produced in a good and correct way [5]. With an understanding of human nature that will never be satisfied, then the quality must be continuously improved to be able to meet customer satisfaction.

Quality improvement is an action that aims to increase the value of a product or service. The quality management system emphasizes on improving the process by using data collected and processed using analytical tools and statistical techniques.

Quality control is about how and what things should be done to reduce the existing variances of the product. Thus, the main objective in methods is to improve product quality by reducing variations in the product.

However, quality improvement through only inspection is not enough. Quality improvement is supposed to be more focused on preventive actions. This can maintain product quality before any damage or disability occurs. By implementing this principle, quality improvement efforts will be able to reduce production costs.

Six Sigma method is often used by companies in product quality control by minimizing the number of defects through the preventive actions. The Six Sigma application focuses on defects and variations, by starting with identifying critical elements of the quality of a process to providing improvement suggestions regarding the defects. Steps to reduce defects and variations are done systematically by defining, measuring, analyzing, fixing and controlling it, known as 5 phases of 
DMAIC. DMAIC is systematically based on science and fact toward the Six Sigma target and of course improves the profitability of the company.

The condition of PT Arwana Citramulia especially in Plant 2B is still less than optimal. A company located at Jalan Raya Serang, Km. No. 69 3, Serang, Banten, Indonesia experienced a decreased in quality and demand from its consumers. Consumer demand decreases due to its product quality that is not optimal. Recognizing to this and the importance of quality, this study aims to reduce the defect rate of ceramic tiles production by applying DMAIC's work steps on Six Sigma.

\section{METHODOLOGY}

The research took place in the production division of ceramic tiles PT Arwana Citramulia on the output of the kiln machine. This research used data defects production period May 2016 until April 2017 used to know the main defect and then conducted quality control analysis with approach DMAIC.

\section{Define}

This stage is an early stage in Six Sigma. At this stage will be the determination of the target and the total number of product defects. This stage is also defined the main defect based on input from customers on product quality data that taken from the previous defects year's data.

\section{Measure}

Some of the things done in this stage are: define a major defect, using a histogram diagram, measure the total DPMO value, and measure the sigma level.

\section{Analyze}

This stage is a stage of analyzing, searching and finding the root cause of a problem using root cause analysis. This can be by using a causal diagram or called Fishbone Diagram. In relation to statistical process control, cause and effect diagrams are used to indicate causal factors and quality characteristics (effects) caused by factors that cause it. [5]

After analyzed using RCA then the research was analyzed using FMEA method. At this stage, FMEA (Failure Mode and Effect Analysis) is used to determine the priority of the improvement plan. FMEA is a systematic activity that identifies and evaluates the potential failure rates that exist in the system, product or process, especially at the root of the product or process functions on factors affecting the product or process. Each type of failure has 1 (one) RPN (Risk Priority Number), which is the result of multiplication between severity, detection, and occurrence rankings. Then the RPN is sorted from the largest to the smallest, so it can be known the most critical type of failure that is a priority for corrective action.

\section{Improve and Control}

This stage is the stage for performing the non-optimal process improvements that known from the previous FMEA methods. Improvement of the process can be done by using tools that have been used but developed or with new tools that have been recommended through this research.

Control stage is a process that has been improved. Controlling can be done by using tools that have been used or with other tools that have been recommended through this research. 


\section{RESULTS}

Citramulia can be seen in the Figure 1.

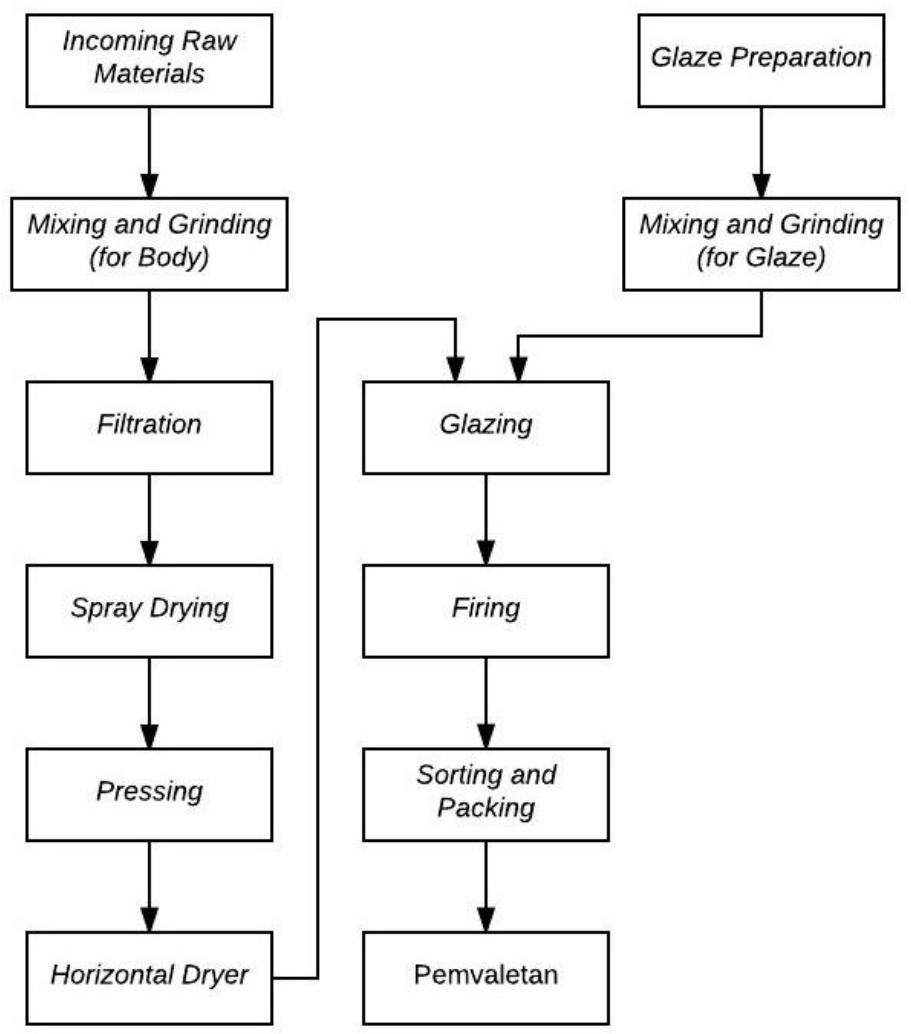

Fig. 1. Production Process in PT Arwana Citramulia.

In this study, observations on the defect products were not performed until the last process or palleting. This research is only done until the output of kiln machine that can be seen in SIPOC (Supplier, Input, Process, Output, Customers) diagram at Figure 2.

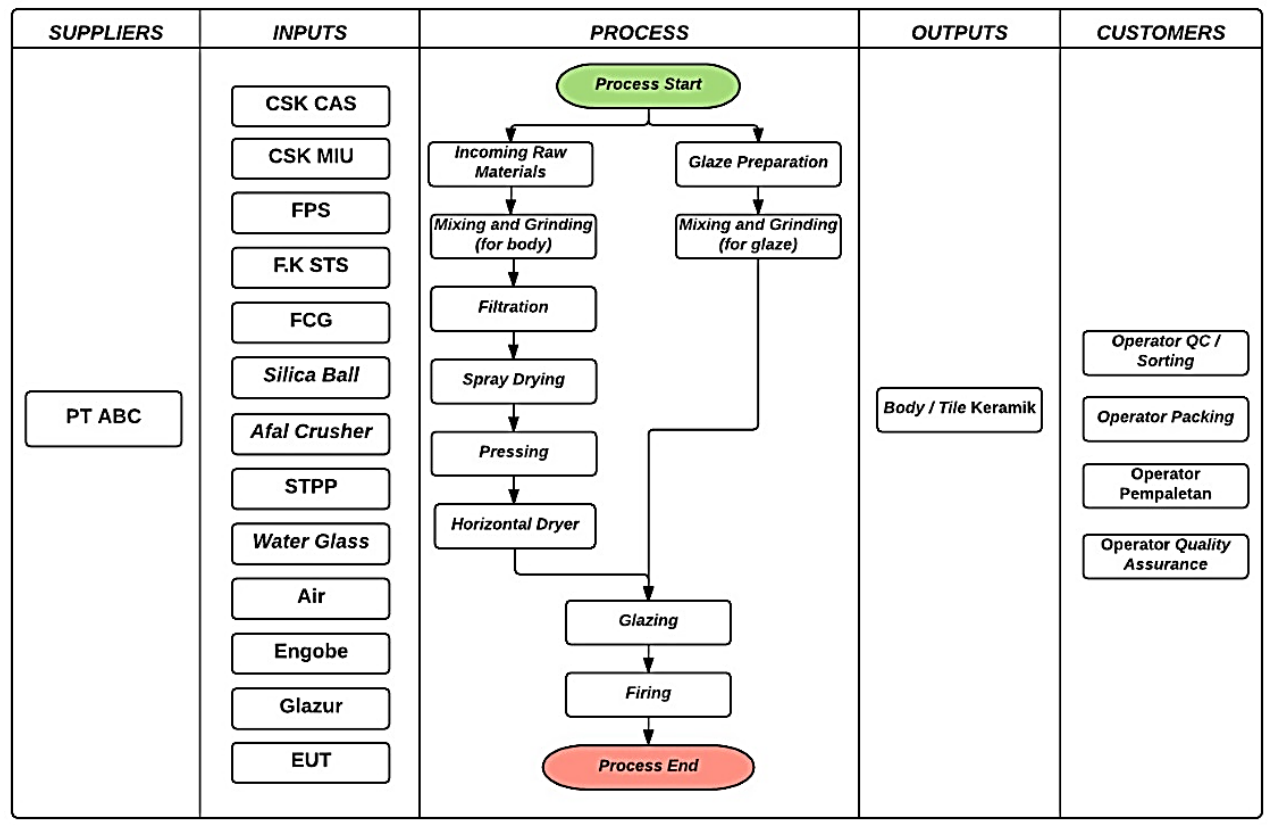

Fig. 2. SIPOC Diagram 
Furthermore, perform the historical data processing of kiln machine production by using Six Sigma step which starts from define, measurement, analyze, and improvement and control (DMAIC).

\section{Define}

In the defining stage, there are 9 types of defects that the customer wants to investigate. In this case, the customer is the operator who works in the quality control, quality assurance, sorting and packing, and spattering. The 9 types of defects are: chop corner, laminate, glaze crack, body impurities, convex or concave, glaze peel, center crack, edge crack, and printing defect. After processing the historical data from production in May 2016 to April 2017, chop corner is a major defect in the production process in this company. So the type of defects that are observed is a chop corner.

\section{Measure}

From the define stage, it is known that the main defect in the tile ceramic production in PT Arwana Citramulia is chop corner. The result of observation of the chop corner product will be used in the next calculation. The observation data were taken within 2 (two) months. The data that taken is the data of tile ceramic products that have chop corner defect after passing the kiln machine as contained in the previous SIPOC diagram. Observations were performed for approximately 30 minutes.

The sigma level of defective product after the kiln machine on tile ceramic products based on direct observation data of May 2017 and June 2017 is 4.13 sigma with 4375 as a value of DPMO.

The measurement of process stability is a measurement to see whether a process is stable or not by using a statistical tool called control chart. The control chart serves to determine whether statistically the process is within control limits or not. In this research, the ceramic tile production process has $\mathrm{UCL}=0.0094$ and $\mathrm{LCL}=0$ with $\mathrm{CL}=0.0044$. It can be seen clearly in the graph below which shows the existence of 1 observation data out of the tolerance limit.

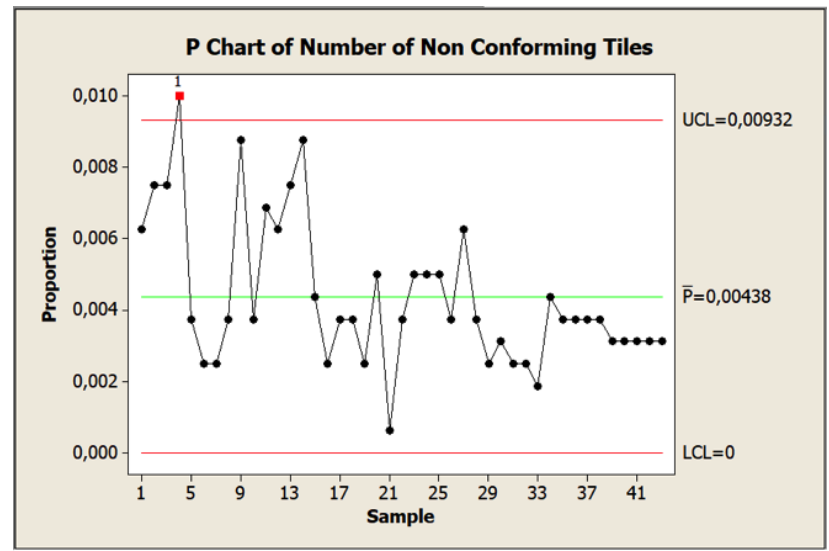

Fig. 3. P Control Chart For Chop Corner Tile Ceramics from May 2017 until June 2017

That out data of the upper control limit must be discarded and perform a new calculation with results of new $\mathrm{UCL}=0.00905, \mathrm{LCL}=0$, and CL $=0.00424$. With this new control limits, the research data from the production process can already be said to be stable. Formula 1 that used for calculate the center line, Formula 2 that used for calculate the upper control limit, and Formula 3 that used for calculate the lower control limit.

$$
\begin{gathered}
\bar{p}=\frac{\sum_{i=1}^{m} D_{i}}{m \cdot n} \\
U C L=\bar{p}+3 \sqrt{\frac{\bar{p}(1-\bar{p})}{n}} \\
L C L=\bar{p}-3 \sqrt{\frac{\bar{p}(1-\bar{p})}{n}}
\end{gathered}
$$




\section{Analyze}

Based on the measure stage, it is known that the dominant defect is a chop corner. Next, an evaluation is performed to determine the cause of each of these defects with a cause and effects diagram that shown in figure 4 .

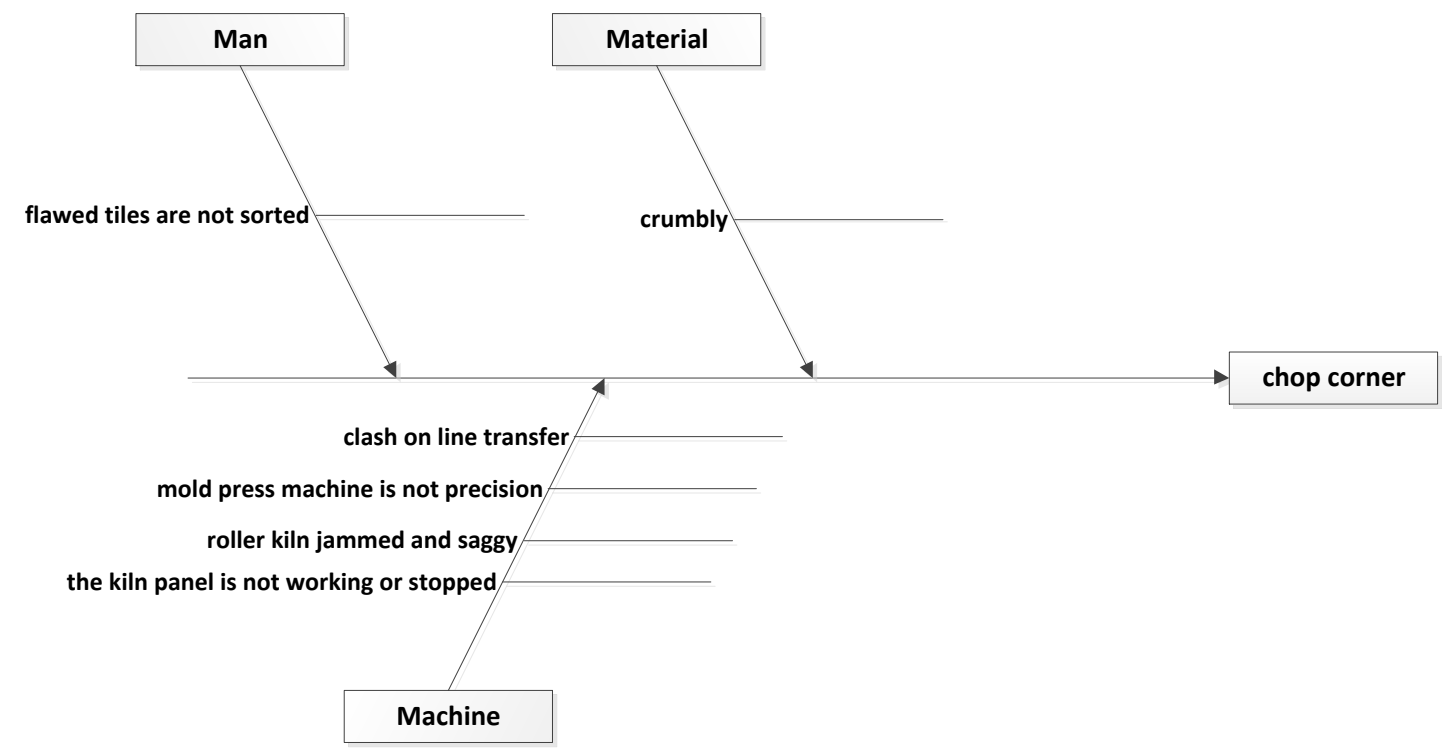

Fig 4. Fishbone Diagram

Through the causal diagram or fishbone diagram in Figure 4 it is explained that the chop corner defect caused by several factors, that are: human factors, machinery, and materials. Based on the Fishbone Diagram in Figure 4, it is known that there are major causes of defect of the ceramic tile, namely the chop corner. The result of causal diagram will be the input for FMEA calculation. Failure Mode and Effect Analysis (FMEA) will generate a Risk Priority Number (RPN) value, which will be a priority improvement scale with the following results in Tabel 1.

TABLE 1 RISK PRIORITY NUMBER (RPN)

\begin{tabular}{|c|l|c|c|c|c|c|}
\hline No & \multicolumn{1}{|c|}{$\begin{array}{c}\text { Potential Failure } \\
\text { Mode }\end{array}$} & Severity & Occurance & Detection & RPN & Priority \\
\hline 1 & $\begin{array}{l}\text { mold press machine is } \\
\text { not precision }\end{array}$ & 5 & 5 & 2 & 50 & 1 \\
\hline 2 & clash on line transfer & 4 & 4 & 3 & 48 & 2 \\
\hline 3 & crumbly & 5 & 3 & 2 & 18 & 5 \\
\hline 4 & $\begin{array}{l}\text { flawed tiles are not } \\
\text { sorted on the kiln } \\
\text { input }\end{array}$ & 4 & 4 & 2 & 32 & 4 \\
\hline 5 & $\begin{array}{l}\text { roller kiln jammed and } \\
\text { saggy }\end{array}$ & 4 & 3 & 3 & 36 & 3 \\
\hline 6 & $\begin{array}{l}\text { the kiln panel is not } \\
\text { working or stopped }\end{array}$ & & & & 10 \\
\hline
\end{tabular}

It can be seen from Table 1 that the main potential failure mode is an imprecise machine presses with RPN value of 50 by multiplying of its severity value, occurrence value, and detection value. 


\section{Improve and Control}

At this stage some suggestions of improvement and control were obtained from the previous results. Proposed improvements and controls are focused on the results of analysis of the importance or priority of the highest RPN values, which is an imprecise press machine presses. The proposed controls are given to control the improvements made in the improvement phase so as to minimize potential failures on the quality of the ceramic tile, so that the ceramic can be optimally produced and in accordance with the standards set by PT Arwana Citramulia.

Improved and control steps are the final two stages in the DMAIC approach. Basically this stage is a control action to the stages that have been previously done, so that documentation, and control becomes an important thing to maintain consistency of improvements made to quality improvement. In this study, the stage of improving and control is not necessarily present and has been implemented to the company, so some suggestions are given, in the hope that future suggestions can be applied or considered for the company. Suggestions for the improve phase are as follows:

\section{Schedule Table Overhaul Press Machine}

It is necessary and important to take detailed and periodic maintenance of the press machine and overhaul machines (repairs totally and thoroughly) conducted once in a year in the hope of producing optimum engine performance. If the performance of the machine is optimal, then the desired quality will be achieved. With the maintenance on the machine it will extend the life of the machine, especially cylindrical liner on the machine.

\section{Documentation of Press Machine Maintenance Process}

Signs clear process is needed in carrying out maintenance and improvement on the process. The procedure of performing the maintenance of the machine needs to be made in order to facilitate the implementation of maintenance and repair on the machine. The implementation of the overhaul of the press machine focuses on communication among staff and the socialization that occurs between the staff and the employees because in this case communication is an important thing in order to avoid misunderstanding between operators, staff, or Head of Department.

\section{Perform Action Planning for Failure Modes}

The proposed improvement is focused on the type of major defect that is a chop corner. Proposed improvements include the action planning for failure modes against the cause of the occurrence of disability chop corner.

The data of previous failure modes through failure modes and effect analysis (FMEA) is used as the basis for making the Action Planning for Failure Modes proposal table that is presented in Table 2 .

TABLE 2 ACTION PLANNING FOR FAILURE MODES

\begin{tabular}{|c|l|l|l|}
\hline Rank & \multicolumn{1}{|c|}{ Failure Mode } & \multicolumn{1}{|c|}{ Actionable Causes } & \multicolumn{1}{c|}{$\begin{array}{c}\text { Design Action/Potential } \\
\text { Solutions }\end{array}$} \\
\hline 1 & $\begin{array}{l}\text { mold press machine is } \\
\text { not precision }\end{array}$ & $\begin{array}{l}\text { line press machine has } \\
\text { worn out }\end{array}$ & $\begin{array}{l}\text { 1. provision of lubricant } \\
\text { regularly }\end{array}$ \\
\cline { 3 - 4 } & & $\begin{array}{l}\text { 2. polishing on the surface of the } \\
\text { liner until clean and clear } \\
\text { periodically }\end{array}$ \\
\cline { 3 - 4 } & clash on line transfer & $\begin{array}{l}\text { pulley transfer line is } \\
\text { broken }\end{array}$ & $\begin{array}{l}\text { pexamination and maintenance } \\
\text { examination and treatment of }\end{array}$ \\
\hline 3 & the kiln panel is not & kiln sensor has error & setting the kiln sensor \\
\hline
\end{tabular}




\begin{tabular}{|c|c|c|c|}
\hline & \multirow[t]{2}{*}{ working or stopped } & & periodically \\
\hline & & $\begin{array}{l}\text { the kiln panel } \\
\text { component is dirty }\end{array}$ & $\begin{array}{l}\text { clean the dirty panels for } \\
\text { preventive steps }\end{array}$ \\
\hline \multirow[t]{4}{*}{4} & \multirow[t]{4}{*}{$\begin{array}{l}\text { roller kiln jammed and } \\
\text { saggy }\end{array}$} & $\begin{array}{l}\text { less precise roller } \\
\text { placement }\end{array}$ & $\begin{array}{l}\text { check and re-locate the roller } \\
\text { appropriately }\end{array}$ \\
\hline & & $\begin{array}{l}\text { rollers are rarely } \\
\text { checked and cleaned }\end{array}$ & $\begin{array}{l}\text { check and clean the roller kiln on } \\
\text { a regular basis }\end{array}$ \\
\hline & & less lubricant roller & provide lubricant regularly \\
\hline & & $\begin{array}{l}\text { roller bearing tear or } \\
\text { stretch }\end{array}$ & $\begin{array}{l}\text { replacing roller bearings with } \\
\text { new and quality }\end{array}$ \\
\hline 5 & $\begin{array}{l}\text { flawed tiles are not } \\
\text { sorted on the kiln input }\end{array}$ & lack of personnel & addition of personnel on sorting \\
\hline 6 & crumbly & $\begin{array}{l}\text { material density is } \\
\text { uneven }\end{array}$ & $\begin{array}{l}\text { checking raw materials, water } \\
\text { content and clay powder }\end{array}$ \\
\hline
\end{tabular}

The suggestions for the control phase are as follows:

\section{Form Control and Maintenance On Knife}

Knife on the press machine is one of the important components because if the knife is not sharp and the shape changes on the knife it will affect the results on the ceramic tile. Therefore, it needs a form of control and maintenance on the knife press machine.

\section{Report Control On Pressure In Press Machine}

Performance indicators of the press machine can be seen from the amount of pressure that provided by the machine. Data can be retrieved regularly from the computer display screen on the machine. With the report form control, the progress of the pressure condition given by the press machine every day can be evaluated so that the press machine condition can always be monitored. Realization in the work field of Plant 2B PT Arwana Citramulia is good enough. The operator has recorded the pressure given by the machine. However, the bookkeeping looks less tidy and it is unclear who is the person in charge of the results that written in the bookkeeping.

\section{Verify The Results of Process Improvement}

The control stage can be by decreasing the DPMO per period and measuring the achievement of the process over a given period of time and controlling and monitoring the results by the Six Sigma project team. So that the desired target performance level of sigma can be achieved with the target time that has been made with the form achievement of performance targets. A progress report on achieving performance targets in a chop corner defect should be evaluated per period. This report form was validated by the head of Department of Plant 2B with the highest authority in the Department of Plant 2B.

\section{Eliminating The Variations}

Maintaining or stabilizing processes by eliminating special causes variables is an important step. Particularly the special causes variable associated with human factors, equipment, and materials that are considered harmful. This can be done by creating a new Fishbone Diagram, where this tool can always be updated. Workers should always try to minimize the variation of the particular cause so that the process can be maintained and stabilized. Stabilization of the process can be done to minimize the variation of the cause, so that the root causes can be suppressed and by making continuous improvements in the company can minimize the factors. 


\section{DISCUSSION}

In this research, the main defect in tile ceramic product of PT Arwana Citramulia is chop corner. Sampling was conducted for 43 days in May 2017 to June 2017. There are several factors that cause defects such as the imprecise press molding machine and the bump on the transfer line. Chop corner and other types of defects can be minimized, but it all depends on how optimized the production process is, so with the optimum production process it could an optimum quality product. Not only that, the understanding of Six Sigma must also be understood by workers so that workers can understand the main purpose of the work that they do.

\section{CONCLUSION}

Based on research that has been done in PT Arwana Citramulia, Serang can be concluded that based on the data defect of the company, there are 9 (nine) types of disabilities that occur on ceramic tile after passing the kiln machine namely; corner compound, laminate, glaze crack, body impurities, convex or concave, glaze peel, center crack, edge crack, and printing defect. The most common defect is a chop corner. With the sigma level of the firms studied from May 2017 to April 2017 is 4.13 sigma. It can be said that the process is quite capable but it needs some effort to improve quality toward the main target of Six Sigma target.

Factors that cause ceramic tile chop corner are human factors, material factors, and factors of machinery and equipment. Failure gained from the labor factor is the performance of the operator is not optimal so there is a tile ceramic defects that are not sorted. Failure from material factor is the water content of clay powder is not in accordance with the standard so as to reduce the density of the material. And the failures derived from engine and equipment factors are problematic kiln panels, jammed and slack kiln rollers, non-precision press machines, and collision on transfer lines.

Proposed improvements are given for the highest value RPN of imprecise press machine molding by proposing a schedule for overhaul of press machine implementation, condition report, evaluation and documenting the maintenance process, and perform action planning for failure modes. The proposed controls are given for the highest RPN of imprecise press machine molds by making form control and maintenance on the blades of the press machine, report control at pressure on the press machine, and verifying the results of routine process improvement by designing performance achievement target form.

\section{REFERENCES}

Anjayani, Indah Dwi, "Analisis Pengendalian Kualitas Produk Dengan Metode Six Sigma Pada CV. Duta Java Tea Industri Adiwerna - Tegal", Skripsi, Semarang: Universitas Negeri Semarang, 2011.

Ardhitama, W, "Proyek Pengembangan Kualitas Menggunakan Penerapan Metode DMAIC Six Sigma Untuk Perbaikan Proses (Studi Kasus pada PT. Musi Hutan Persada)", Yogyakarta : Universitas Gadjah Mada, 2004.

Besterfield, Dale H, "Quality Control: Seventh Edition”, New York: Prentice Hall, 2004.

Caesaron, Dino dan Stenly Yohanes P., "Implementasi Pendekatan DMAIC Untuk Perbaikan Proses Produksi Pipa PVC (Studi Kasus PT. Rusli Vinilon)”, Jurnal Metris, Jakarta: Universitas Bunda Mulia, 2015.

Gaspersz, Vincent, "Pedoman Implementasi Six Sigma Terintegerasi dengan ISO 9001: 2000 MBNQA dan HCCP”, Jakarta: PT. Gramedia Pustaka Umum, 2002.

Hanif, Rukmi, dan Susy Susanty, "Perbaikan Kualitas Produk Keraton Luxury Di PT X Dengan Menggunakan Metode Failure Mode and Effect Analysis (FMEA) dan Fault Tree Analysis (FTA)”, Jurnal: Institut Teknologi Nasional, Juli 2015.

Harahap, Sandra Aprilia, "Analisis Pengendalian Kualitas Produk Keripik Pisang Puri Jaya Pada PD. Puri Jaya Di Bandar Lampung”, Skripsi, Bandar Lampung: Universitas Lampung, 2016.

JIM, Vol. 3, No. 2, Juli 2018, pp.101-110 
Montgomery, Douglas C, “Introduction to Statistical Quality Control Fifth Edition”, New York: John Wiley and Sons, 2005.

Pande, S. Peter, “The Six Sigma Way Handbook, Bagaimana GE, Motorolla dan Perusahaan Terkenal Lainnya", Yogyakarta: Penerbit ANDI, 2002.

Pyzdek, T, “The Six Sigma Handbook: Complete Guide for Greenbelts, Blackbelts, and Managers at All Levels", New York: McGraw - Hill, 2001.

Windarti, Tantri, "Pengendalian Kualitas Untuk Meminimasi Produk Cacat Pada Proses Produksi Besi Beton", Jurnal, Surabaya: STMIK Surabaya, 2014. 
